\title{
Geography Information System (GIS) and Geography Teaching Material
}

\author{
*Bithi Arifa ${ }^{1)}$ and Kumar Suker ${ }^{2)}$
}

1) Bangladesh National Geographycal Association (BNGA)

2) Department of Geography and Environment Jahangirnagar University

Email: bithiariva@gmail.com

*Corresponding Author, Received: May 12, 2018, Revised: May 23, 2018, Accepted: June 03. 2018

\begin{abstract}
GIS technology applies geographic science with tools for understanding and collaboration. It helps people reach a common goal: to gain actionable intelligence from all types of data. GIS integrates many different kinds of data layers using spatial location. Most data has a geographic component. GIS data includes imagery, features, and basemaps linked to spreadsheets and tables. Spatial analysis lets you evaluate suitability and capability, estimate and predict, interpret and understand, and much more, lending new perspectives to your insight and decision-making.
\end{abstract}

Keywords: Geography, Geography Information System, Teaching Material

\section{Introduction}

Until quite recently, geographical information systems have been limited to the resources and students of post-secondary institutions. This situation is now changing in Ontario. In the early 1990's the Ministry of Education adopted mandates to develop curriculum guidelines for the integration of computers into all areas of the curriculum. Although the process is well underway in Ontario, limited access to hardware and software, insufficient pre-service and in-service training, and a paucity of teaching resources has lead to mounting teacher frustration. Although the literature base on teaching GIS at the pre-collegiate level is increasing, it lacks clearly defined examples of how to teach geography through GIS technology. This thesis proposes a model GIS curriculum which applies GIS functionality to the teaching of geographic concepts and skills. This curriculum was developed in conjunction with the WLU GIS Certificate Course program which provided a unique opportunity to develop and evaluate the model curriculum.

The program participants, who consisted of teachers already in-service, became not only the subjects of the research, but also active participants in the development of curricula. The teachers provided valuable feedback and evaluation by addressing both conceptual and practical concerns. In this way, the research was not only exploratory and collaborative, but also pragmatic. In particular, the model GIS curriculum was designed with needs of the teachers in mind. Many lessons were learned from working with teachers in the GIS Certificate Course program. These lessons can be grouped into three categories, namely, the in/pre- service distinction, the teaching with/about GIS dichotomy, and the recognition that "less is more". Conceptually, the model GIS curriculum is fuelled by a novice-expert transition which provides a progression from the most basic skills and knowledge of geography and GIS, to more expert levels of interpretation, analysis and modelling. The model GIS curriculum introduced in this thesis consists of four substantive units and seven projects (Hermon, 2014; Hermon, 2017). 
These projects are based on the application of Idrisi to problems of geographical inquiry and the representation of physical and human landscapes. Units 1 and II provide a general introduction to basic GIS and cartographic theory, and Units III and IV branch out into human and physical environments. In addition to providing a detailed strategy to guide teachers in their instruction, the model GIS curriculum also provides a set of pedagogical benefits for students. These benefits focus on making the learning process more relevant thus, creating student satisfaction in the learning process. These benefits would include the strengthening of critical thinking skills and the application of GIS technology into real-world situations. This model GIS curriculum is now in need of further development, namely, it needs to meet the needs of a changing audience. A prescribed curriculum, as proposed in this thesis will have a short lifespan and become redundant as more teachers gain pre- service training in GIS.

To accommodate the changing nature of the secondary school sector, a parallel system of curriculum might be appropriate. In this parallel system, the in-service educator would be served by a model GIS curriculum as proposed by this thesis, and the pre-service educator with teacher preparation models. In addition to creating a parallel system of curriculum, another challenge presents itself in the further integration of GIS at the secondary school level. This challenge centres on maintaining a focus on the instruction of geographical analysis while making the GIS technique as transparent as possible. Further research on learning and cognition is also required. One aspect would be the determination of skill and knowledge outcomes which could be used to test control groups: one consisting of students trained using traditional Method of instruction, and the other using the model GIS curriculum to determine the performance indicators and whether the model GIS curriculum does indeed improve critical thinking skills. Finally, it is important for educators to maintain an open dialogue on the application of GIS to the secondary school classroom to make it a viable option.

\section{Spatial Data Tools}

Geographic information systems (GIS), remote sensing, and the global positioning system (GPS) are tools used extensively by researchers, scientists, and civic planners to assist decision-making about real world problems. Application of this technology to such concerns as the environment, agriculture, land use management, and infrastructure development is occurring on local, regional, and national levels. In particular, GIS is a powerful tool for storing, analyzing, displaying, and processing spatially referenced information. While these spatial data resources have been used widely in business, industry, and government agencies, data availability, awareness, training opportunities, and hardware limitations such as high student-to-computer ratios, low capacity processors, and insufficient random access memory (RAM) and hard drive memory. Recent advances in hardware capabilities and relative reduction in costs have resulted in the introduction of powerful, affordable, personal computers in schools that can be used to run GIS software and manipulate large spatial data sets. Additionally, software companies such as Environmental Systems Research Institute (ESRI) and Clark Labs have produced software bundles designed for school systems at affordable educational prices. Now that supportive technologies are more readily available, educators are beginning to use GIS and GPS technology in fifth- through twelfth-grade teaching and learning environments. Examples are varied and range from students researching and creating GIS layers of American Civil War battles (Alibrandi, 2001), to mapping community hazards in Detroit (Wilds and Martin 2005), to examining connections between geography, history, and technology in the context of the Underground Railroad (Bloom and Palmer-Moloney, 2004). Other students have become involved in mapping and analyzing data relevant to local environmental issues (Bull, Bull, and Mason 1999; Paul and Hamilton 2000; Queen, Easterling, and Connors 1998).

\section{Spatial Teaching}

In recent years, researchers and teachers from the natural sciences, social sciences, and even the humanities have begun integrating spatial analysis tools into their classrooms. Spatial thinking engages students in problem-based research and peer-to-peer construction of knowledge. Using spatial tools fosters the higher order thinking skills of Bloom's taxonomy, like evaluation, synthesis, analysis, and application, and builds long-lasting knowledge. People and things inhabit space, so geographic approaches are well-suited for showing spatial (and temporal) variation in characteristics, or attributes, of objects at multiple scales, from 
individual to population, to state, and nation levels (Scaffidi, 2015). A GIS (Geographic Information System) incorporates data capturing hardware (computers and GPS, or Global Positioning Systems, like on your cell phone), and software (ESRI's ArcMap is the industry standard, while GRASS and MapWindow GIS are some freeware applications), based on various geographic projections and coordinate systems (Hermon, 2014; Hermon et al., 2018).

A GIS helps researchers and teachers quickly depict large quantities of data efficiently and dynamically. A GIS helps us explore how our data vary geographically or spatially. For example, in the image above, study site locations are represented by the blue crosshairs, and our GIS study investigates how data (ordinal, nominal, or quantitative) vary based on elevation, distance, and other geographic characteristics. Mapping data allows us to quickly visualize data, but also enables researchers and teachers to develop and test new hypotheses that might not have been evident from just looking at data tables. For example, a researcher could ask where the statistical center of a polygon is, where the next nearest-neighbor is from one data point to another, or what areas are visible from a mountain peak. The possibilities are absolutely endless for involving students not only in data collection, but in the development of research questions and hypothesis testing through GIS-based analyses. The geographic approach closely mirrors the scientific method, and offers teachers a way to teach research design at all age levels.

The advantages of using GIS in teaching include getting students out of the classroom and into the field to gather data. GIS-based collaborative projects allow students to interpret and integrate new lines of data and ask new research questions after initial collection. With one set of data represented in a GIS, for example, an instructor could change the symbols and types of data that are represented, and challenge students to interpret these new maps. Data interpretation and visualization are higher-order skills that are difficult to cultivate in students (yes, even in data-driven disciplines), and the flexibility of data depiction in a GIS allows ample opportunities for students to work their interpretive muscles out.

Along with teacher participation and workshop development, this investigation also considered the level and type of use by the teachers who participated. As might be expected by the spread of grade levels and content areas, the complexity of the lesson plans varied. Generally, the elementary, middle school, and art teachers used GIS to conduct visual investigations without accessing advanced querying capabilities of the software. For instance, a sixth-grade teacher designed a lesson using GIS to introduce her students to the five themes of geography by looking at such things as the characteristics and features of a place. An art teacher asked her students to use GIS to investigate landforms and landmarks and then create their own landmark stamps. The students then used these stamps along with principles of design and printmaking skills to create new maps of the areas under investigation (Hermon et al., 2018).

The junior high and high school science, geography, and mathematics teachers tended to use more of the software' s functionality. Three examples of teachers' work demonstrating a more complex level of use are presented here. An eighth-grade science teacher prepared and tested a lesson about which physical features of an area need to be considered before drilling an oil well. She wrote: The purpose is to prepare students for our Oil Rig Simulation by getting them to think about what problems may occur because of natural and human features, and what things could be affected by drilling a well. Students will eventually be asked to write Environmental Impact Statements for Drilling. By looking at actual features around actual wells, we can start discussing the potential problems they may need to address. A junior high earth science teacher designed a plan in which the students would investigate seismic activity and the associated seismic risks in Yellowstone National Park by posing questions and scenarios.

The teacher reported: Does the number and location of seismic events remain relatively constant each year in the park? Do significant seismic events occur near areas of sustained human use, so that some assessment of the likely risk of a seismic event occurring can be conducted? The quake events would have to be examined in relationship to the physical environment of the park (mountains, valleys, rivers, geysers) as well as the human features there (roads, campgrounds, visitor stations, etc.). Not only could the students point out the relative likelihood of seismic events in areas of current use in the park, but they could also provide some information on potential high-risk areas that should be avoided. 


\section{Conclusion}

First and foremost, find a research problem or an issue that can be addressed with spatial data. Situating your learning objectives for students within a real-world context will give students a chance to think critically about the data sets they are using (if gathered from other researchers), how they are going to collect their own data, and how their project articulates with current research. Leave yourself plenty of time to learn the software! ArcMap and freeware GIS programs can be challenging to learn and computationally-intensive. If you plan on using GIS as part of a hands-on learning exercise in your classroom, you should plan to start learning the GIS program you will use, at least 1-2 months before hand. Many users report having to spend at least 2-4 hours outside of class time each week just learning the basics of map-making and data display in ArcMap. Check out the resources below for more information about how instructors have used GIS in their classrooms to guide active learning exercises.

\section{References}

Alibrandi, M. (2001). Mapping Life and Society: Integrating Geographic Information Systems Into Social Studies. Curriculum Technology 11(1).

Audet, R., and G. L. Abegg. (1996). Geographic Information Systems: Implications for Problem Solving. Journal of Research in Science Teaching. Vol. 33. No. 1: 21-45.

Audet, R., and J. Paris. (1997). GIS Implementation Model for Schools: Assessing the Critical Concerns. Journal of Geography. Vol. 96. No. 6: 293-300.

Baker, T. (2005). Internet-Based GIS Mapping in Support of K-12 Education. The Professional Geographer. Vol. 57. No. 1: 44-50.

Beth Scaffidi. (2015). https://www.coloradocollege.edu/other/gis/teaching-with-gis.html.

Bloom, E., and J. Palmer-Moloney. (2004). Meeting the Challenge: Integrating Geographic Technology into Today's Social Studies Classroom. Meridan Middle School Computer Technologies Journal. www.ncsu.edu/meridan/win2004/gis/.

Bohlin, R. M., and N. P. Hunt. (1995). Course Structure Effects on Students Computer Anxiety, Confidence and Attitudes. Journal of Educational Computing Research. Vol. 13. No.3: 263-270.

Bull, G., G. Bull, and C. L. Mason. (1999). Online Geographic Information Systems: Using Real-World Data to Explore Layers of Meaning. Learning and Leading with Technology. Vol. 26. No. 4:42-45.

Darling-Hammond, L. (1998). Teacher Learning that Supports Student Learning. Educational Leadership. 55 (5): 6-11.

Drennon C. (2005). Teaching Geographic Information Systems in a Problem-Based Learning Environment. Journal of Geography in Higher Education. Vol. 29. No. 3: 385-402.

Fagin TD, and Wikle T.A. (2011). The Instructor Element of GIS Instruction at US Colleges and Universities. Transactions in GIS. 15 (1): 1-15.

Fullen, M. G., and M. Miles. (1992). Getting Reform Right: What Works and What doesn't. Phi Delta Kappa. 73 (10): 745-752.

Garet, M., A. Porter, L. Desimone, B. Birman, and K. Suk Yoon. (2001). What Makes Professional Development Effective? Results from a National Sample of Teachers. American Educational Research Journal. Vol. 38. No. 4: 915-945.

Hermon, D. (2014). Geografi Bencana Alam. Radjawali Press

Hermon, D. (2017). Climate Change Mitigation. Rajawali Pers (Radjagrafindo). Jakarta

Hermon, D., A. Putra., and O. Oktorie. (2018). Suitability Evaluation of Space Utilization Based on Enviromental Sustainability at The Coastal Area of Bungus Bay in Padang City, Indonesia. Vol. 14, Issu 41: 193-202.

Hermon, D., Ganefri., A. Putra., and O. Oktorie. (2018). The Model of Mangrove Land Cover Change for the Estimation of Blue Carbon Stock Change in Belitung Island-Indonesia. International Journal of Applied Environmental Sciences. Vol. 13. Number 2: 191-202 
Hopkins, K. D. (1998). Educational and Psychological Measurement and Evaluation 8th ed. Needham Heights, Madsen LM, and Rump C. 2012. Considerations of How to Study Learning Processes when Students use GIS as an Instrument for Developing Spatial Thinking Skills. Journal of Geography in Higher Education. 36 (1) : 97-116.

McClurg PA, and A. Buss. (2007). Professional Development: Teachers Use of GIS to Enhance Student Learning. Journal of Geography. Vol. 106. No. 2: 79-87.

Keiper, T. A. (1999). GIS for Elementary Students: An Inquiry into a New Approach to Learning Geography. Journal of Geography. Vol. 98. No. 2: 47-59.

Kerski, J. J. (2003). The Implementation and Effectiveness of Geographic Information Systems Technology and Method in Secondary Education. Journal of Geography. Vol. 102. No. 3: 128-137.

Lemberg, D., and J. P. Stoltman. (1999). Geography Teaching and the New Technologies: Opportunities and Challenges. Journal of Education. Vol. 181. No. 3: 63-76.

Lester, J. (2003). Planning Effective Secondary Professional Development Programs. American Secondary Education. Vol. 32. No. 1: 49-61.

Loucks-Horsley, S., P. W. Hewson, N. Love, and K. E. Stiles. (1998). Designing Professional Development for Teachers of Science and Mathematics Thousand Oaks, California: Corwin Press, Inc

Malone, L., A. Palmer, and C. Voigt. (2002). Mapping Our World: GIS Lessons for Educators. Redlands, California: ESRI Press.

McClurg, P., and A. Buss. (2000). Developing Prairie to Mountain Explorer: A GIS and Remote Sensing Data Set For the Fifth-Twelfth Grade Classroom. In Proceeding of M/SET 2000. ed. R. Robson. Chesapeake, Virginia: Asociation for the Advancement of Computing in Education (AACE).

McClurg, P., H. Copeland, M. O’ Neill, A. Buss, R. Shafer, P. Cantrell, B. Malik, and P. Thanapura. (1999). Prairie to Mountain Explorer. Grand Forks, North Dakota: Education Public Access Resource Center. Upper Midwest Aerospace Consortium.

McClurg, P., and H. Lerner. (1998). Using GIS in the Earth System Science Internet Project. Geo Info Systems. 8 (3) : 34-37.

Paul, W., and W. Hamilton. (2000). Hazmat. In GIS in schools, eds. R. Audet and G. Ludwig, pp. 13-21. Redlands, California: ESRI Press.

Patterson TC. (2007). Google Earth as a (not just) Geography Education Tool. Journal of Geography. Vol. 106. No. 4: $145-152$.

Queen, A. M., H. Easterling, and V. Connors. (1998). Teaching Young Researchers GIS: From Wetlands to the Web. Geo Info Systems March: 38-41.

Ramirez, M. (1996). A Driving Force in Technology Education: Geographic Information Systems (GIS). TechTrends 41 (2): 34-36.

Read JM. (2010). Teaching Introductory Geographic Information Systems through Problem-based Learning and Public Scholarship. Journal of Geography in Higher Education. Vol. 34. No. 3: 379-399.

Songer LC. (2010). Using Web-Based GIS in Introductory Human Geography. Journal of Geography in Higher Education. Vol. 34. No. 3: 401-417.

Slater, T. F., B. P. Beaudrie, and R. L. Fixen. (1998). Implementing K-12 Hypermediated Earth System Science Activities Based on World-Wide Web Resources. Journal of Geoscience Education. Vol. 46. No. 2: 149-153.

Wilds, R., and D. Martin. (2005). Urban Safety Program. http://maps.culma.wayne.edu/info.htm. 